\title{
Art Music by Caribbean Composers: Antigua and Barbuda
}

\section{Christine Gangelhoff \\ The College of The Bahamas ${ }^{1}$ \\ Cathleen LeGrand Royal Thimphu College, Bhutan}

\section{INTRODUCTION}

The island nation of Antigua and Barbuda (which includes the third island of Redonanda) was discovered by Columbus in 1493. The larger and more populous island was named for Santa Maria de la Antigua, a cathedral in Seville. While colonists from Spain and France attempted to settle the islands, the British were the most successful colonists (Kaufman, 2005). Antigua and Barbuda continued under British rule from 1632 until independence in 1981 (McDaniel, 1998). Both islands are flat and fertile, ideal locations for the sugar plantations that dominated much of the West Indian economy of the 17th and 18th centuries. Agriculture (both cultivation and processing of agricultural products) remains a smaller but still important industry in Antigua and Barbuda (Canedo, 2008).

Most of the small population is descended from the West Africans brought to the islands as slaves. Antigua and Barbuda "remain devoid of the interracial minglings that typify the populations of other Caribbean islands" (McDaniel, 1998, p. 798).

The steelpan was introduced from Trinidad in 1945 and quickly gained popularity (De Jong, 2005). The first steelband in the Caribbean, the Hell's Gate Steel Orchestra, was formed in the late 1940's and is still a force in the Antiguan steelpan scene (De Jong, 2005). More steel bands quickly arose and "the steelpan became the center of cultural life on Antigua and Barbuda" (De Jong, 2005, para. $3)$.

As on many other Caribbean islands, the annual Carnival is a major cultural event. Antigua and Barbuda hold separate Carnival celebrations, Antigua's being the larger and more elaborate (De Jong, 2005).

\footnotetext{
${ }^{1}$ Christine Gangelhoff, Assistant Professor, School of Communication and Creative Arts, The College of The Bahamas, P.O. Box N-4912, Nassau, Bahamas; Cathleen LeGrand, Librarian, Royal Thimphu College, Ngabiphu, Thimphu, Bhutan.

Acknowledgments: The authors would like to thank the following for their contributions to and assistance with this chapter: Marion Byron and Khan Cordice.

E-mail: cgangelhoff@cob.edu.bs

APA reference: Gangelhoff, C., \& LeGrand, C. (2013). Art music by Caribbean composers: Antigua and Barbuda. The International Journal of Bahamian Studies, 19(2), 4-5. Retrieved from http://journals.sfu.ca/cob/index.php/files/article/view/185/246
} 


\section{REFERENCES}

Canedo, V. F. (2008). Antigua and Barbuda. In Africa and the Americas: Culture, politics, and history. Retrieved from http://0-www.credoreference.com.helin.uri. edu/entry/abcafatrle/antigua_and_barbuda

De Jong, N. (2005). Antigua and Barbuda. In Continuum encyclopedia of popular music of the world: Locations. Retrieved from http://www.credoreference.com/entry/cont pmwl/antigua_and_barbuda
Kaufman, W. (2005). Antigua and Barbuda. In Britain and the Americas: Culture, politics, and history. Retrieved from http://0-www.credoreference.com.helin.uri. edu/entry/abcbramrle/antigua_and_barbuda

McDaniel, L. (1998). Antigua and Barbuda. In D.A. Olson \& D.E. Sheehy (Eds.), Garland encyclopedia of world music, volume 2 (pp. 798-800). London, England:

Routledge.

\section{COMPOSERS}

Walter G. P. Chambers

Khan Cordice (1990- )

Yvonne Maginley

Howell Rock

George Roberts

\section{COMPOSITIONS, by composer}

\section{Chambers}

Fair Antigua, we salute thee (adopted 1967, national anthem of Antigua and Barbuda)

\section{Maginley}

Where land and sea makes beauty

\section{RECORDINGS}

\section{Chambers}

National anthems of the world, vol. 1 [CD]. (2006). Hong Kong: Marco Polo.

Catalogue no. 8.225319

Track 17. Fair Antigua, we salute thee (arranged by Peter Breiner, 1:13)

\section{SOUND FILES}

\section{Chambers}

Fair Antigua, we salute thee. (2013). http://www.nationalanthems.me/antiguaand-barbuda-fair-antigua-we-salute-thee/

\section{BOOKS AND ARTICLES}

Hillhouse, J. C. (2012, 11 Sept.). Talking music and more with Khan Cordice. Antigua Observer. Retrieved from http://www.antiguaobserver.com/talkingmusic-and-more-with-khan-cordice 